\title{
Pembentukan Biofilm Pseudomonas aeruginosa pada Beberapa Media Cair
}

\section{Formation of Pseudomonas aeruginosa Biofilm on Some Liquid Media}

\author{
Didik Wahyudi ${ }^{*}{ }^{*}$, Endang Sutariningsih Soetarto ${ }^{2}$ \\ * corresponding author: didik.wahyudi@stikesnas.ac.id \\ ${ }^{1}$ Program Studi Teknologi Laboratorium Medis, Sekolah Tinggi Ilmu Kesehatan Nasional, Jl. Raya \\ Solo - Baki, Kwarasan, Grogol, Sukoharjo, Jawa tengah, Indonesia \\ ${ }^{2}$ Fakultas Biologi, Universitas Gadjah Mada, Jl. Teknika Selatan, Sekip Utara, Sleman 55281, \\ Yogyakarta, Indonesia. \\ Riwayat Artikel: Diterima September 2021; Diterbitkan Oktober 2021
}

\begin{abstract}
Abstrak
Pseudomonas aeruginosa merupakan bakteri Gram negatif berbentuk batang bersifat patogen oportunistik yang menjadi penyebab utama infeksi nosokomial dan mampu membentuk biofilm pada media pertumbuhan, biofilm sering mengakibatkan pengobatan penyakit infeksi menjadi lebih sulit. Media pertumbuhan bakteri ada beberapa jenis, komposisi dan merek. Tujuan penelitian ini adalah untuk mengetahui kemampuan $P$. aeruginosa dalam membentuk biofilm pada beberapa media biakan cair. $P$. aeruginosa diisolasi dari sampel klinis dari rumah sakit, media cair yang digunakan adalah nutrien broth, laktosa broth, brain-heart infusion (BHI), luria bertani broth, dan tripticase soy broth. Uji pembentukan biofilm menggunakan metode microtiter plate culture technique, kemampuan pembetukan biofilm diukur berdasarakan optical density dengan menggunakan microtiter plate reader pada panjang gelombang $570 \mathrm{~nm}$, dengan pewarnaan crystal violet $0,1 \%$, setelah inkubasi 24 jam pada suhu $37^{\circ} \mathrm{C}$, dengan replikat 8 kali. Hasil penelitian menunjukkan bahwa $P$. aeruginosa memiliki kemampuan membentuk biofilm pada nutrient broth $0,926 \pm 0,081$, laktosa broth 0,521 $\pm 0,041, B H I 1,283 \pm 0,031$, luria bertani $1,301 \pm 0,043$, dan media trypticase soy broth $1,563 \pm 0,032$. Pembentukan biofilm tertinggi pada trypticase soy broth, dan terendah pada laktosa broth, sedangkan pada media BHI dan luria bertani kemampuan pembentukan biofilm yang setara. Kesimpulan penelitian ini adalah $P$. aeruginosa memiliki kemampuan yang berbeda dalam membentuk biofilm ketika ditumbuhkan pada media cair yang berbeda.
\end{abstract}

Kata kunci : Biofilm, Pseudomonas aeruginosa, media cair.

\begin{abstract}
Pseudomonas aeruginosa is a Gram-negative rod-shaped bacterium that is an opportunistic pathogen that is the main cause of nosocomial infections and is able to form biofilms on growth media, biofilms often make the treatment of infectious diseases more difficult. There are several types of bacterial growth media, compositions and brands. The purpose of this study was to determine the ability of $P$. aeruginosa to form biofilms on several liquid culture media. $P$. aeruginosa was isolated from clinical samples from hospitals, the liquid media used were nutrient broth, lactose broth, brain-heart infusion (BHI), luria bertani broth, and tripticase soy broth. The biofilm formation test used the microtiter plate culture technique method, the ability to form biofilms was measured based on optical density using a microtiter plate reader at a wavelength of $570 \mathrm{~nm}$, with $0.1 \%$ crystal violet staining, after 24 hours incubation at $37^{\circ} \mathrm{C}$, with 8 replications. The results showed that $P$. aeruginosa had the ability to form biofilms in nutrient broth $0.926 \pm 0.081$, lactose broth $0.521 \pm 0.041, B H I$ $1.283 \pm 0.031$, luria bertani $1,301 \pm 0.043$, and trypticase soy broth media $1.563 \pm 0.032$. The highest biofilm formation was in trypticase soy broth, and the lowest was in lactose broth, while in BHI and luria farming media the biofilm formation abilities were equivalent. The conclusion of this study is that $P$. aeruginosa has different abilities in forming biofilms when grown on different liquid media.
\end{abstract}

Key words: Pseudomonas aeruginosa, biofilm, liquid media. 


\section{Pendahuluan.}

Pseudomonas aeruginosa merupakan bakteri berbentuk batang, bersifat gram negatif, memiliki kemampuan membentuk biofilm di dalam media biakan, dan substrat yang dilekatinya (Wahyudi et al., 2019 dan Khoiriah, 2021). Bakteri ini telah banyak ditemukan pada kasus infeksi klinis di beberapa bagian tubuh dan menyebabkan pengobatan menjadi lebih sulit (Lee et al., 2018). P. aeruginosa sering ditemukan menjadi penyebab infeksi nosokomial, yaitu infeksi yang di dapatkan seseorang ketika berada di rumah sakit (ArcaSuárez et al., 2019; Angeletti et al 2018). Kasus tertinggi $P$. aeruginosa menyebabkan kistik fibrosis (Pallett et al, 2019), infeksi saluran pernafasan ('Tovar-García et al., 2020), infeksi saluran kemih (Wahyudi \& Rahmawati, 2021), infeksi pada luka (Wahyuni (2020), dan beberapa infeksi lain yang bisa ditemukan pada banyak sampel klinis, antara lain sputum, urin, luka, cairan cerebrospinal, pus, feses, infeksi pasca bedah (Wahyudi, 2019; Milanda, 2021).

$P$. aeruginosa merupakan bakteri yang mampu tumbuh pada beberapa media dan kondisi lingkungan, secara sifat fisiologinya bakteri ini memiliki kemampuan menghidrolisis protein (gammaproteobacteria) (Kamal et al, 2021), dan tidak mampu menghidrolisis karbohidrat (glukosa, laktosa, mannitol, maltose, dan sukrosa) (Bengi et al. 2020). $P$. aeruginosa mampu memfermentasikan citrat yang ada dalam biakan untuk dijadikan sebagai sumber energinya. Beberapa penelitian menunjukkan bahwa $P$. aeruginosa membentuk biofilm pada berbagai situasi dan kondisi lingkungan (Wahyudi et al, 2019; Fatima, 2020; Annisa et al., 2021). Kemampuan pembentukan biofilm ini banyak dikaitkan dengan kejadian resistensi terhadap antibiotik (Hilda, 2017; Wahyudi, 2019; Cepeda, 2021). Fatima (2020) menyatakan bahwa ada hubungan yang signifikan antara pembentukan biofilm pada Pseduomonas aeruginosa dengan tingkat resistensi antibiotiknya.

Pembentukan biofilm $P$. aeruginosa dipengaruhi oleh beberapa faktor antara lain, komposisi nutrient (karbohidrat, protein), kondisi lingkungan $(\mathrm{pH}$ dan suhu pertumbuhan), serta senyawa inhibitor yang lain (Wahyudi et al., 2019)). Pembentukan biofilm bakteri di dalam tubuh sangat merugikan, karena pengobatan infeksi menjadi lebih rumit. Beberapa kasus infeksi ditemukan bahwa kejadian infeksi bakteri yang disertai pembentukan biofilm semakin banyak ditemukan. Penelitian berskala in vitro membutuhkan informasi mengenai faktorfaktor yang menunjang dan menghambat pembentukan biofilm $P$. aeruginosa (Annisa et al., 2021). Informasi mengenai kemampuan pembentukan biofilm $P$. aeruginosa di dalam media cair bakteri menjadi satu hal yang sangat penting dan belum digali dan diteliti, tujuan penelitian ini adalah untuk mengetahui kemampuan pembentukan biofilm pada $P$. aeruginosa dalam beberapa media cair, sehingga hasil penelitian ini dapat dimanfaatkan sebagai acuan bagi penelitian yang berhubungan dengan pembentukan biofilm pada $P$. aeruginosa.

\section{Metode Penelitian}

Alat

Autoclave (Astel), inkubator (Heraeus), oven (Heraeus), laminar air flow, waterbath; refrigerator (National), spektrofotometer (Shimadzu UV mini 1240), microplate reader (Bio-Rad iMark), vortex (Whirli Mixer FISONS), shaker (AS-One RM-300), centrifuge (Eppendort ${ }^{\mathrm{R}}$ ), mikropipet dan tip (Eppendorf $\left.{ }^{\circledR}\right)$, timbangan elektrik (ZJMZYM JM-B Analytical), aluminium foil, rak tabung reaksi, kertas saring, $\mathrm{pH}$ meter (Metrohm 691), electrophoresis apparatus.

\section{Bahan}

Kultur murni isolat P. aeruginosa (Pa29-d), Media Mac Conkey (Merck), Medium LuriaBertani(LB) (Oxoid), Nutrient Broth (NB) (Sigma-Aldrich), Trypticase Soy Broth (TSB) (Oxoid), Media brain-heart infusion (BHI) (Merck), Laktosa broth (Oxoid) crystal violet 0,1 \%, etil alkohol 95: $20 \mathrm{ml}$, ammonium oksalat, akuades.

\section{Tahapan Penelitian}

\section{Purifikasi isolat $\boldsymbol{P}$. aeruginosa}

Isolat $P$. aeruginosa dari sampel sputum pasien dirumah sakit yang telah teridentifikasi dengan Vitek 2 Compact, digoreskan pada permukaan media agar Mac Conkey dengan teknik goresan dalam cawan petri (streak plate), diinkubasi pada suhu $37^{\circ} \mathrm{C}$ selama 24 jam. Koloni yang tumbuh terpisah diambil dan dipindahkan ke media Nutrient Agar miring sebagai biakan murni. Penyiapan biakan murni P. aeruginosa dilakukan untuk pengujian selanjutnya dengan membuat sub kultur cair dari masing-masing kultur, yaitu 
menginokulasikan ke $10 \mathrm{~mL}$ media Nutrient broth, diinkubasi pada suhu $37 \mathrm{oC}$, selama 24 jam (Axler-DiPerte, 2017).

2. Uji pembentukan biofilm pada beberapa media cair.

Biakan murni isolat $P$. aeruginosa diuji kemampuannya dalam membentuk biofilm pada media cair menggunakan metoda sumuran plat (microtiter plate 96 well method) (Hassan et al., 2012). Biakan murni P. aeruginosa diremajakan pada suhu $37^{\circ} \mathrm{C}$ dan diinkubasi selama 24 jam, dibuat dengan standar kekeruhan 0,5 Mc. Farland. Biakan murni $P$. aeruginosa yang berada di media cair diambil $2 \mu$ l dimasukkan ke dalam sumuran plat yang telah diisi dengan $198 \mu \mathrm{l}$ media biakan cair uji (5 jenis), yaitu: Nutrien Broth, Laktosa Broth, Brain-Heart Infusion (BHI), Luria Bertani Broth, dan Tripticase Soy Broth, diinkubasikan selama 24 jam pada suhu $37^{\circ} \mathrm{C}$. Masing-masing kultur pada media cair dibuat ulangan sebanyak 8 kali. Kontrol negatif menggunakan media cair tanpa di tambahkan kultur bakteri. Biofilm yang terbentuk akan melekat pada dasar sumuran, cairan media kultur dibuang dan dicuci tiga

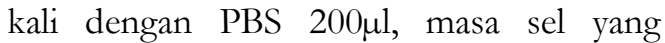
melekat dicat dengan $0,1 \%$ crystal violet, lalu dicuci dengan akuades sebanyak 5 sampai 7 kali (menggunakan pipet), diresuspensi dengan $200 \mu \mathrm{l}$ acid isopropanol $5 \%$. Suspensi $P$. aeruginosa yang membentuk biofilm diukur secara spektrometri $(\lambda=570$ $\mathrm{nm})$, berdasarkan optical density dengan menggunakan microtiter plate reader(Hassan $e t$ al., 2012, Wahyudi et al., 2019).

\section{Analisa Data}

Biofilm yang terbentuk diukur sebagai nilai optical density dari pembacaan hasil pengukuran pada microplate reader. Hasil pengurkuran dianalisis dengan ANOVA pada taraf kepercayaan $95 \%$, dan dilanjutkan dengan uji perbedaan antara 5 kelompok media dan kontrol dengan post hoc test. Analisis dilakuakan dengan aplikasi SPSS 23.

\section{Hasil dan Pembahasan}

$P$. aeruginosa hasil isolasi dari sampel sputum memiliki karakteristik sebagai berikut, pada fermentasi di media Klinger iron Agar (KIA) menunjukkan Alkali/Alkali, artinya bakteri tidak memfermentasikan glukosa dan laktosa, tidak menghasilkan $\mathrm{H}_{2} \mathrm{~S}$ baik pada media KIA maupun SIM, namun terlihat motil, dan memfermentasikan citrat sebagai satu-satunya sumber karbon, tidak mampu tumbuh pada media Methilen red, Voges Proskanver, urea, dan tidak memfermentasikan semua media karbohidrat (glukosa, laktosa, maltose, mannitol, dan sukrosa). Karakteristik pertumbuhan bakteri tersebut terlihat bervariasi, diawali dengan pembentukan filamen, yang dimulai dari permukaan, kemudian terus berkembang ke bagian bawah media (Gambar 1).

Uji pembentukan biofilm $P$. aeruginosa menunjukkan kemampuan yang bervariasi ketika bakteri ini ditumbuhkan pada media cair yang berbeda. Meskipun isolat yang sama, umur biakan sama, lama dan suhu inkubasi yang sama, serta kekeruhan yang sama, namun pada media yang berbeda, terlihat pembentukan biofilmnya juga berbeda-beda (Tabel 1). Hal ini menunjukkan bahwa ada pengaruh yang signifikan kontribusi jenis media cair yang digunakan dengan kemampuan pembentukan biofilm $P$. aeruginosa.

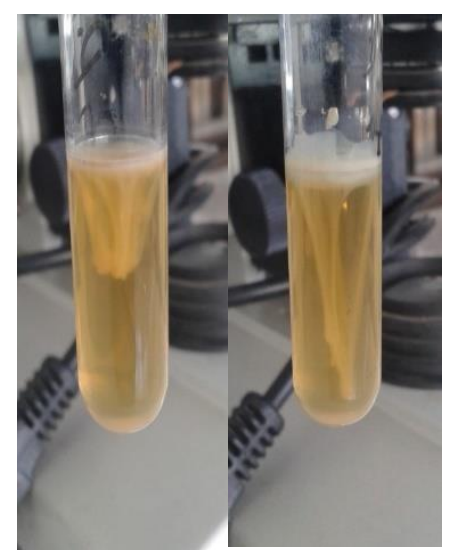

\section{Gambar 1. Karakteristik pertumbuhan $P$. aeruginosa pada media cair (BHI)}

Gambar 2 dan Tabel 1 menunjukkan bahwa pembentukan biofilm tertinggi pada media TSB yaitu: 1,563 , sedangkan terendah pada media LB 0,521, jika dilihat selisih angka optical density-nya terlihat sangat jauh sekitar 1,0. Hasil uji pembentukan biofilm pada media BHI dan LBB berdasarkan analisis statistik terlihat sama kemampuannya, namun masih lebih tinggi dibandingkan pada media NB. Jika kita cermati secara fungsional semua media tersebut adalah media penyubur universal, yang bertujuan menumbuhkan semua jenis bakteri, dan memang 
terlihat dengan jelas bahwa isolat $P$. aeruginosa mampun tumbuh dengan baik ketika ditumbuhkan disemua media, namun kemampuannya membentuk biofilm terlihat berbeda satu media dengan media yang lain

Tabel 1. Hasil pembentukan biofilm $P$. aeruginosa pada beberpa media cair.

\begin{tabular}{lcc}
\hline \multicolumn{1}{c}{ Media } & $\begin{array}{c}\text { Rerata } \\
\text { Massa } \\
\text { Biofilm }\end{array}$ & SD \\
\hline Nutrien Broth (NB) & $0,926^{\mathrm{a}}$ & 0,181 \\
Laktosa Broth (LB) & $0,521^{\mathrm{b}}$ & 0,141 \\
BHI Broth & $1,283^{\mathrm{c}}$ & 0,131 \\
$\begin{array}{l}\text { Luria bertani broth } \\
\text { (LBB) }\end{array}$ & $1,301^{\mathrm{cd}}$ & 0,143 \\
$\begin{array}{l}\text { Tripticase Soy Broth } \\
\text { (TSB) }\end{array}$ & $1,563^{\mathrm{d}}$ & 0,132 \\
\hline
\end{tabular}

Ket: Huruf yang sama menunjukkan tidak berbeda signifikan pada uji BNJ 5\%.

Pembentukan biofilm pada media TSB terlihat paling tinggi sebabkan media ini terdiri dari berbagai komposisi yang mendukung dalam pembentukan biofilm antara lain; casein peptone (pancreatic) digunakan sebagau sumber nitrogen mineral dan vitamin, seperti diketahui bahwa $P$. aeruginosa merupakan bakteri yang bersifat proteolotik, mampu membentuk energi dari sumber protein (kelompok gammaproteobacteri). Selain itu pada media TSB terdapat Soya peptone (papainic) yang merupakan sumber energy ganda untuk pertumbuhan dan pembentukan biofilm. Hal ini sesuai dengan hasil penelitian Bengi et al. (2020) yang menyatakan bahwa $P$. aeruginosa tidak memfermentasikan karbohidrat namun menggunakan protein sebagi sumber karbonnya. Wahyudi et al. (2019) juga menyatakan hal yang sama bahwa $P$. aeruginosa hasil isolasi dari sampel klinis terlihat lebih mampu membentuk biofilm ketika ditambahkan unsur protein, yaitu asam amino tryptophan.

Pembentukan biofilm pada media LB terlihat paling rendah hal ini disebabkan media LB hanya terdiri dari laktosa saja, sedangkan telah diketahui $P$. aeruginosa tidak mampu menggunakan laktosa secara langsung untuk mendukung pertumbuhannya, sehingga $P$. aeruginosa membutuhkan mekanisme tambahan untuk mampu memanfaatkan laktosa hal tersebut terjadi jika dalam satu biakan ada bakteri jenis lain yang bersimbiosis (Arca-Suárez et al., 2019). Media Luria bertani dan BHI menunjukan kemampuan yang setara bagi $P$. aeruginosa untuk membentuk biofilm, ini disebabkan kedua media tersebut mengandung unsur pepton dan ekstrak khamir, yang kaya akan asam amino untuk mendukung pembentukan eksopolisakarisa dan matrik penyusun biofilm (Kamal et al., 2021).

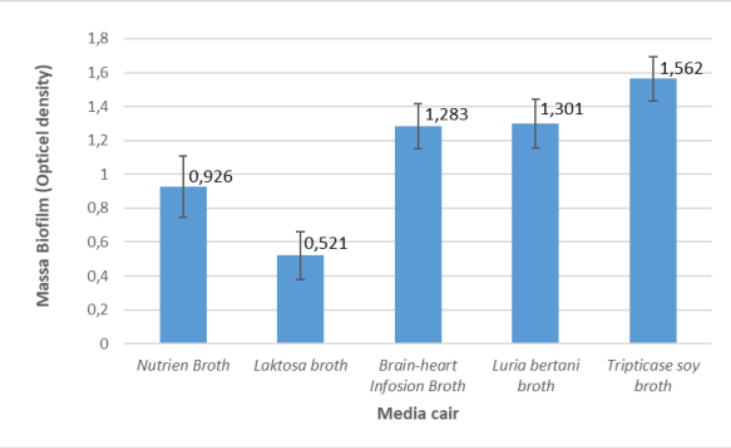

\section{Gambar 2. Grafik hasil pembentukan biofilm pada beberapa media cair.}

Media dengan komposisi senyawa pepton, ekstrak khamir, unsur-unsur protein, mineral dan sumber karbon, serta kaya unsur nitrogen berkontribusi terhadap pembentukan biofilm $P$. aeruginosa. Hal tersebut didukung dengan hasil penelitian Kamal et al. (2021), Lee et al., (2018), dan Annisa et al., (2021). Media pertumbuhan dengan komposisi unsur karbohidrat tunggal, kurang mampu mendukung pembentukan biofilm $P$. aeruginosa. Hasil penelitian ini bisa dipergunakan sebagai acuan bagi peneliti-peneliti berikutnya dalam pemilihan media pertumbuhan $P$. aeruginosa kaitannya dengan kemampuan pembentukan biofilm. Namun perlu diperhatikan bahwa untuk spesies bakteri yang lain perlu dilakukan uji lebih lanjut, hal ini disebabkan proses pembentukan biofilm pada satu bakteri dengan bakteri lain memiliki mekanisme yang spesifik dan dikendalikan oleh gen pengendali yang berbeda (Lee et al., 2018), dan matriks atau komponen penyusun biofilm (eksopolisakarida) yang spesifik pada masing-masing spesies bakteri (Pallett et al., 2019; Kamal et al., 2021). 


\section{Simpulan}

$P$. aeruginosa memiliki kemampuan yang berbeda dalam membentuk biofilm ketika ditumbuhkan pada media cair yang berbeda. $P$. aeruginosa memiliki kemampuan membentuk biofilm tertinggi pada media trypticase soy broth dan terendah pas media Laktosa broth, Sedangkan pada media Brain-Heart Infusion dan Luria Bertani menunjukkan kemampuan pembentukan biofilm yang setara

\section{Ucapan Terima Kasih}

Penulis mengucapkan terima kasih kepada LPPM STIKES Nasional yang telah mendukung pendanaan penelitian, dan kepada Laboratorium Pusat Studi Bioteknologi UGM yang telah memfasilitasi pelaksanaan penelitian ini.

\section{Daftar Pustaka}

Angeletti, S., Cella, E., Prosperi, M., Spoto, S., Fogolari, M., De Florio, L., \& Ciccozzi, M. (2018). Multi-drug resistant Psendomonas aeruginosa nosocomial strains: Molecular epidemiology and evolution. Microbial pathogenesis, 123, 233-241.

Annisa, K., Sutarno S., \& Santosa, S. (2021). Azolla microphylla and Pseudomonas aeruginosa for bioremediation of bioethanol wastewater. Biodiversitas Journal of Biological Diversity, 22(4).

Arca-Suárez, J., Fraile-Ribot, P., Vázquez-Ucha, J. C., Cabot, G., Martínez-Guitián, M., Lence, E., \& Oliver, A. (2019). Challenging antimicrobial susceptibility and evolution of resistance (OXA-681) during treatment of a long-term nosocomial infection caused by a Pseudomonas aeruginosa ST175 clone. Antimicrobial agents and chemotherapy, 63(10), e01110-19.

Axler-DiPerte G L., 2017. Modeling and Visualizing Bacterial Colony Purification Without the Use of Bacteria or Laboratory Equipment. J Microbiol Biol Educ. 18(2): 241-255

Bengi, W. T. M., Erina, E., \& Darniati, D. (2017). Isolasi dan Identifikasi Psendomonas aeruginosa pada kasus Ear mites Kucing domestic (Felis domesticus) di Kecamatan Syiah Kuala, Banda Aceh
(Isolation and Identification Pseudomonas aeruginosa in the Case of Ear mites of Domestic cat (Felis domesticus) in the Sub district of Syiah Kuala, Banda Aceb). Jurnal Ilmiah Mahasiswa Veteriner, 1(2).

Cepeda, G. N. (2021). Karakteristik Antibakteri Minyak Essensial Daun Drimys piperita Terhadap Pertumbuhan Bakteri Resisten Antibiotik. Agrointek, 15(1), 162-170.

FATHIMA, R. (2020). Uji Aktivitas Antibiofilm Minyak Atsiri biji Kopi Arabika (Coffea Arabica L) Gayo Terhadap Psendomonas aeruginosa ATCC 27853. ETD Unsyiah.

Hilda, H. (2017). Pola Resistensi Bakteri Staphylococus Aureus, Escherichia Coli, Pseudomonas Aeruginosa Terhadap Berbagai Antibiotik. Husada Mahakam: Jurnal Kesehatan, 4(1), 11-17.

Kamal, S. M., Simpson, D. J., Wang, Z., Gänzle, M., \& Römling, U. (2021). Horizontal transmission of stress resistance genes shape the ecology of beta-and gammaProteobacteria. Frontiers microbiology, 12.

Khoiriah, A. N. (2021). Uji aktivitas antibiofilm aspergillus aculeatus terhadap biofilm psendomonas aeruginosa (Doctoral dissertation, Universitas Islam Negeri Maulana Malik Ibrahim).

Lee, Y., Song, S., Sheng, L., Zhu, L., Kim, J. S., \& Wood, T. K. (2018). Substrate binding protein DppA1 of $\mathrm{ABC}$ transporter DppBCDF increases biofilm formation in Pseudomonas aeruginosa by inhibiting Pf5 prophage lysis. Frontiers in microbiology, 9, 30.

Milanda, T., Mustikawati, S., \& Chaerunisaa, A. Y. (2021). Aktivitas Antibakteri Fraksi Teraktif Kulit Batang Trengguli (Cassia fistula L.) Terhadap Propionibacterium acnes Isolat Klinis dan Pseudomonas aeruginosa ATCC 27853 dalam Sediaan Salep. Journal of The Indonesian Society of Integrated Chemistry, 13(1), 1-13.

Pallett, R., Leslie, L. J., Lambert, P. A., Milic, I., Devitt, A., \& Marshall, L. J. (2019). Anaerobiosis influences virulence properties of Psendomonas aeruginosa cystic fibrosis isolates and the interaction with Staphylococcus aureus. Scientific reports, 9(1), 1-18. 
Tovar-García, A., Angarita-Zapata, V., Cazares, A., Jasso-Chávez, R., Belmont-Díaz, J., anchez-Torres, V., \& García-Contreras, R. (2020). Characterization of gallium resistance induced in a Pseudomonasaeruginosa cystic fibrosis isolate. Archives of microbiology, 202(3), 617-622.

Wahyudi D, Aman AT, Handayani NSN, Soetarto ES. 2019. Differences among clinical isolates of Pseudomonas aeruginosa in their capability of forming biofilms and their susceptibility to antibiotics. Biodiversitas 20(5): 14501456.DOI: $10.13057 /$ biodiv/d200538
Wahyudi, D. (2019). Uji Kepekaan Sel Biofilm Pseudomonas aeruginosa Terhadap Ciprofloxacin dan Amikacin Secara In Vitro. Jurnal Farmasi Journal of Pharmacy), 1(1), 16-22.

Wahyudi, D., \& Wael, S. (2021). Pengaruh Ekstrak Alpinia galanga L Terhadap Produksi Biofilm pada Escherichia coli. Jurnal Farmasi Journal of Pharmacy), 10(1, Maret), 24-30.

Wahyuni, R. A. (2020). Ekspresi Tnf-a Dan Peningkatan Jumlab Pembulub Darah Pada Luka Insisi Tikus Rattus Norvegicus Yang Diinfeksi Pseudomonas Aeruginosa Terhadap Pengaruh Pemberian Ekstrak Aloe Vera Secara Topikal(Doctoral dissertation, Universitas Airlangga). 